\title{
A Bamboo-Hybrid-Slat Laminate of Fishing Boat: Materials Selection, Scantling Calculation and Construction Cost
}

\author{
Heri Supomo ${ }^{1 *}$ ), Eko Budi Djatmiko²), Wikaranosa Supomo3), Rizki Dian Permana ${ }^{4)}$ \\ 1) Department of Naval Architecture, Faculty of Marine Technology, Sepuluh Nopember Institute of Technology \\ ${ }^{2)}$ Department of Ocean Engineering, Faculty of Marine Technology, Sepuluh Nopember Institute of Technology \\ 3) Baito Deling Research \\ 4) National Research and Innovation Agency of Indonesia \\ *) Corresponding Author : h.supomo1964@gmail.com
}

\section{Article Info}

Abstract

\section{Keywords:}

Hybrid Slat Laminate;

Bambusa arundinacea;

Pterocarpus indicus;

Scantling;

Construction Cost;

\section{Article history:}

Received: 21/09/2021

Last revised: 03/11/2021

Accepted: 04/11/2021

Available online: 04/11/2021

Published: 04/11/2021

\section{DOI:}

https://doi.org/10.14710/kapal. v18i3.41559

\begin{abstract}
Laminated bamboo slats (especially Bambusa arundinacea) have been studied since 2013 to replace solid teak wood as a fishing boat construction material. However, laminated bamboo slats preserve high production costs to be used as fishing boat construction material even though the bamboo population is quite large. To reduce the production costs, it is necessary to combine bamboo with other materials. Pterocarpus indicus is a suitable material to be combined with bamboo as a laminate material because it is a bio-material that is cheap, easy to cultivate, fast-growing and renewable. From the tests that have been carried out, it was found that this hybrid material meets the requirements of BKI as a ship's construction material $(42.169 \mathrm{MPa}$ for tensile strength and $72.098 \mathrm{Mpa}$ for flexure strength). This material has the highest tensile strength of $114.636 \mathrm{MPa}$ (tested with ASTM D3500 standard) and the highest flexure strength of $111.606 \mathrm{MPa}$ (tested with ASTM D3024 standard) with the configuration of parallel slats. This material is also cheaper than solid teak wood when used as a 20 GT fishing boat's construction material. The volume of laminated bamboo hybrid slats material needed is $28.7 \%$ lower and the construction cost $40.66 \%$ less than Teak wood material.
\end{abstract}

Copyright ( 2021 KAPAL : Jurnal Ilmu Pengetahuan dan Teknologi Kelautan. This is an open access article under the CC BY-SA license (https://creativecommons.org/licenses/by-sa/4.0/).

\section{Introduction}

Solid teak wood is the main material for making traditional fishing boats in Indonesia. Uncontrolled illegal logging from 1999-2013 resulted in forest destruction. Until now, the damaged forest has reached > 1.13 million hectares per year [1,2]. The scarcity of solid teak makes the price even more expensive. Thus, the activity of traditional shipyards, especially those that produce fishing boats has decreased quite drastically [3].

This condition encourages to always develop alternative substitute materials for Teak wood as ship construction material. In several studies, Dendrocalamus asper and Bambusa arundinacea slats have been used in fishing boat construction $[4,5]$. Based on the utilization study of those two types of bamboo, it was concluded that the mechanical properties were satisfactory and could reduce the construction size up to 65\% [6]. However, the ship production cost using laminated bamboo slats is quite high because the production process requires a lot of adhesive and labour. Bamboo slats need to be combined with other materials since its lack of thickness. Thus, by combining bamboo with other material, it will reduce the number of lamination layer, adhesive consumption and labour [7].

One of the innovations in this research is the combined lamination of Pterocarpus indicus slats with Bambusa arundinacea slats. Pterocarpus indicus slats were chosen for several reasons: fast growth rate, can be planted with seeds or stem cuttings, thrives in various types of land, spread throughout Indonesia, and the price is relatively cheaper (IDR 3,000,000 per m3) [8]. Pterocarpus indicus is classified as Strength Class III and Durability Class III with tensile strength of $70.10 \mathrm{MPa}$ and flexure strength of 52.15 MPa. Based on regulations from the Indonesian Classification Bureau (BKI), Pterocarpus indicus is technically still suitable to be used as the construction material for fishing boats [9,10].

In its application as a ship construction material, there has been no research that combines Pterocarpus indicus and Bambusa arundinacea into a hybrid laminate material. Hence, it is necessary to know the mechanical strength of the hybrid lamination material using both materials. This mechanical strength is also influenced by the fiber's direction of the slats. Thus, it is necessary to test the strength with various fiber direction in order to know which the strongest variation is.

This study aims to create a hybrid laminate material between Bambusa arundinacea and Pterocarpus indicus that can be used as a fishing boat construction material. Therefore, this research analyse the mechanical strength with consideration 
of the material's fiber direction. In addition, this study also examines the economic value of the hybrid laminate material by calculate the production cost using this material. Hopefully, with this new material, the high price of fishing boats due to the scarcity of teak wood can be subdued.

\section{Methods}

In choosing a material that meets the requirements of the Indonesian Classification Bureau regulations, it is mandatory to test the mechanical properties of Bambusa arundinacea hybrid slats lamination with Pterocarpus indicus. This test is carried out by varying the fibre directions of the Pterocarpus indicus slats to obtain the most appropriate material. Following the Indonesian Classification Bureau volume VII 2017, the tensile strength test is carried out applying the ASTM D3500 standard [11], while flexure testing refers to ASTM D3043 [12]. To get a more representative result in terms of the laminate arrangement of the slats, mechanical properties testing was carried out on hybrid laminated boards with several variations in the direction of the slats of the Pterocarpus indicus to Bambusa arundinacea.

\subsection{Material Preparation}

The mechanical properties testing begins with making hybrid laminated boards of Bambusa arundinacea and Pterocarpus indicus. The dimension of the boards is $700 \times 150 \times 25(\mathrm{~mm}$ ) for flexure test and $500 \times 150 \times 25$ (mm) for tensile test. Those laminated boards are made by stacking Bambusa arundinacea slats and solid Pterocarpus indicus alternately. All layers are stuck together with an epoxy polyamide adhesive.

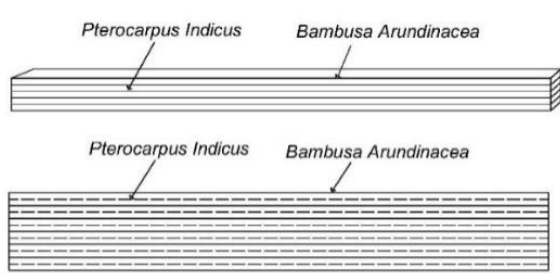

(a) Parallel $\left(0^{\circ}\right)$

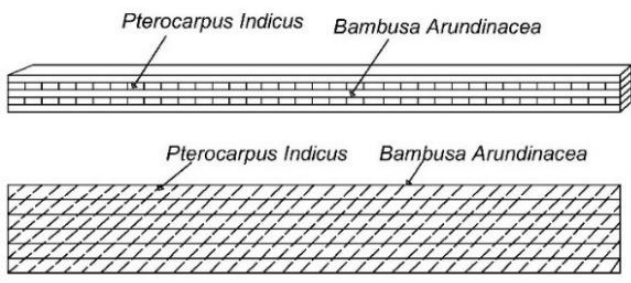

(c) Transverse $\left(45^{\circ}\right)$

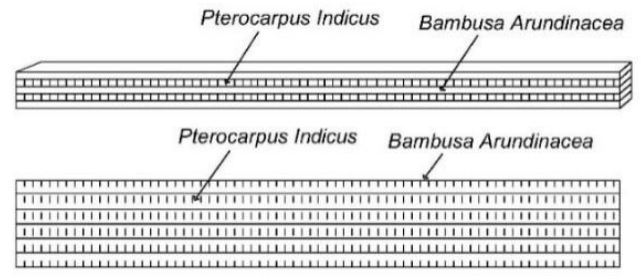

(b) Transverse $\left(90^{\circ}\right)$

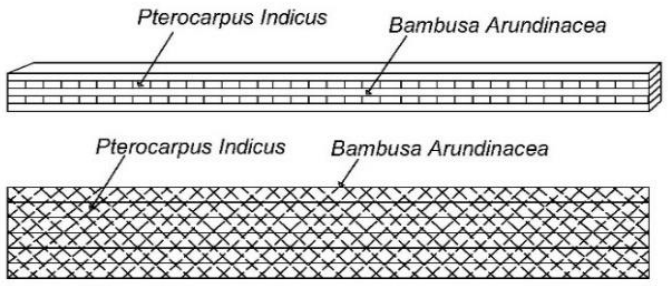

(d) Combined Transverse of $\left(45^{\circ}\right)$ and $\left(135^{\circ}\right)$

Figure 1. Variation of angle between Pterocarpus indicus against Bambusa arundinacea slats

There are four variations in the fibre direction of the Bambusa arundinacea slats: parallel $\left(0^{\circ}\right)$; transverse $\left(45^{\circ}\right.$ and $\left.90^{\circ}\right)$; and cross-crossing $\left(45^{\circ}\right.$ and $\left.135^{\circ}\right)$. This variation is based on the material's ability to withstand loads from several directions and later adjusted to the variation of the angle of the Pterocarpus indicus wood slats to the direction of the Bambusa arundinacea slats. These variations are made to provide the best possible choice of hybrid slats laminate material. For more details, it can be seen in Figure 1.

The laminate boards that have been made according to variations in the angle of slat are then cut allowing to the shape and size of the specimen. In accordance with the ASTM D3500 standard, the shape and size of the tensile test specimen for the hybrid laminated material of the Bambusa arundinacea with Pterocarpus indicus can be seen in Figure 2a [11]. While the flexure test specimen based on the ASTM D3024 standard are described in Figure 2b [12]. The number of each test specimens: tensile and flexure test is 5 (pieces) $\mathrm{x}$ (variation of slats direction) $=15$ pieces.
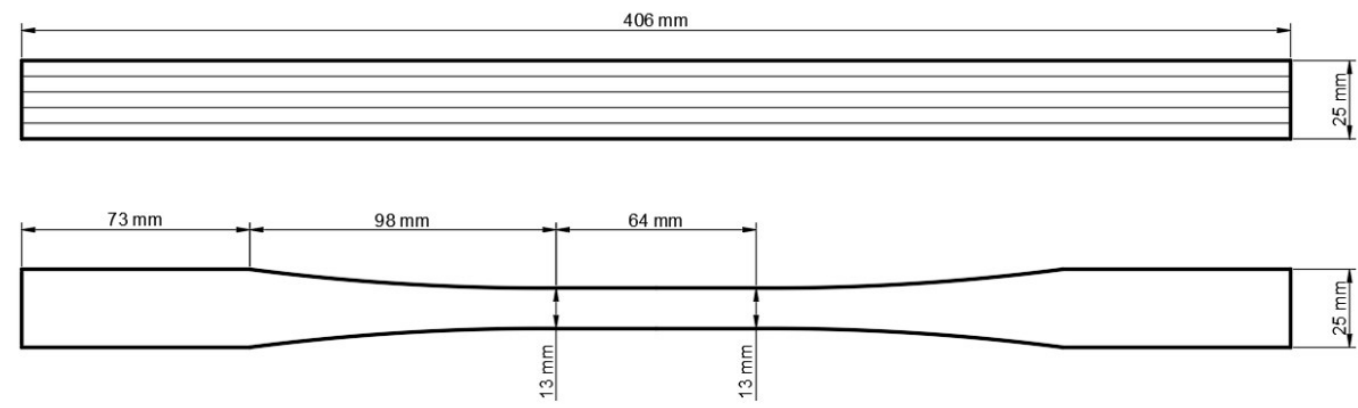

(a) Tensile test specimen 


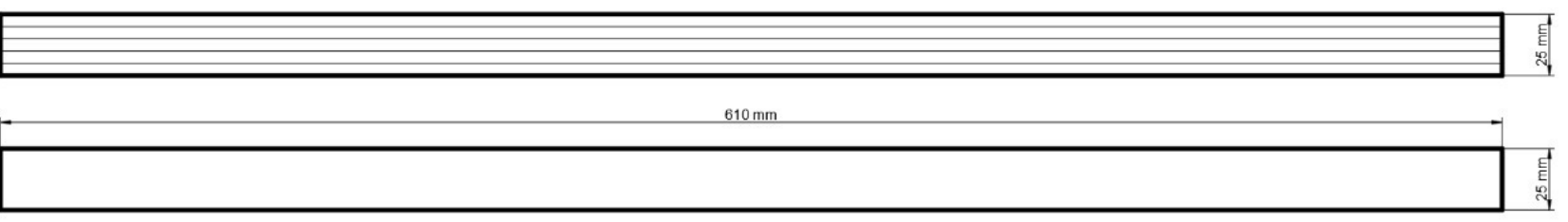

(b) Flexure test specimen

Figure 2. Specimen test of (a) tensile and (b) flexure

\subsection{Tensile and Flexure Test}

The tensile and flexure test is carried out using a UTM MFL / UFD machine with load capacity up to 200kN at a speed of $2 \mathrm{~mm} /$ minute. This test was carried out following ASTM standards (D3500 for tensile test and D3024 for flexure test) [11,12]. The purpose of this test is to determine the tensile and flexural strength of each specimen. Before the test is conducted, it must be assured that the test specimen has no defects. The testing process can be seen in Figure 3.

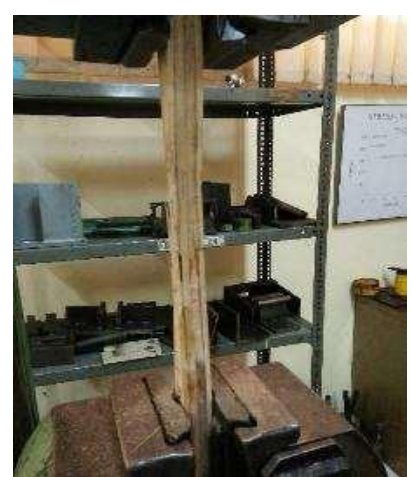

(a) Tensile Test

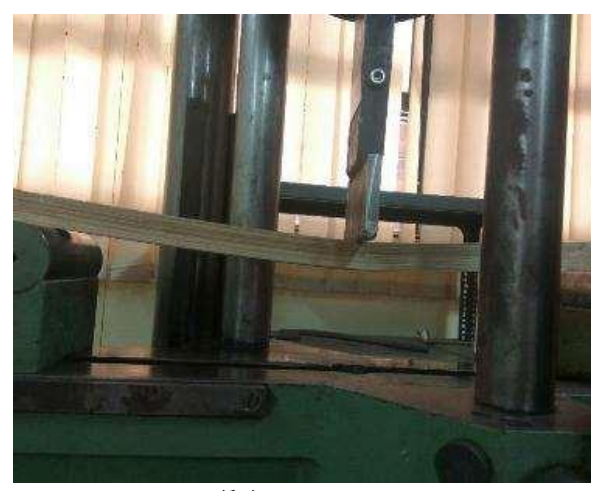

(b) Flexure Test

Figure 2. Mechanical testing process

The results of the tests are then represented through load vs deflection graph. The maximum load on the graph represents the ultimate strength condition. Furthermore, the UTM result graph must be converted into a stress vs deflection diagram. The highest strength value stated in the graph then used as the tensile or flexure strength of the material.

The tensile and flexure strength values used to calculate the elastic modulus of the material. A predetermined calculation can identify the modulus of elasticity (MoE) based on the results of the tensile test under ASTM D3500 [11], which can use the following formula:

$$
M o E=\frac{l}{A}\left(\frac{\Delta \mathrm{P}}{\Delta l}\right)
$$

Where in Equation 1. is calculated, the modulus of elasticity is obtained by multiplying the separation of the length of the specimen (1) and the cross-section area of the specimen (A) with the value of the load $(\Delta \mathrm{P})$ and the elongation of the specimen $(\Delta \mathrm{l})$.

The calculation of Flexure strength (MOR) is carried out using formula listed in ASTM D3024, namely [12]:

$$
M O R=\frac{3 P l}{2 b t^{2}}
$$

Regarding to Equation 2, calculation of the modulus of rupture (MoR) or flexure strength is done by multiplying three times of load (P) with length of span (1). Those value then divided by two times of specimen's face (b) and the square of specimen's web $(\mathrm{t})$.

Substituting the values obtained from the experiment which include: the length of the specimen (l); width of the specimen (b), thickness of the specimen $(t)$ and deflection $(\delta)$. So that the modulus of elasticity of the flexure test specimen is obtained correctly.

The calculation of the modulus of elasticity $(\mathrm{MoE})$ in the bending strength test is carried out using the formula listed in ASTM D3043, namely [12]:

$$
M o E=\frac{l^{3}}{4 b t^{3}} \delta
$$


According to Equation 3, to determine the modulus of elasticity, it is done by substituting the values obtained from the experiment which include: the length of the specimen (l); width of the specimen (b), thickness of the specimen ( $t$ ) and deflection $(\delta)$. So that the modulus of elasticity of the flexure test specimen is obtained correctly.

\section{Results and Discussion}

This research provides technical analysis derived from the tensile and flexure test result. The test results will state which variation of fibre direction has the best tensile and flexural strength. In addition, this study also focuses on the analysis of the economic value of fishing boat construction which is simulated using a 20 GT fishing boat.

\subsection{Tensile Test Results}

The results of the calculation of tensile strength can be seen in Table 1. The results of the tensile test on each of the 5 specimens have several individual properties. The difference in the value of this test according to the ASTM D-3500 standard guidelines is still permissible to be used and analyzed. By calculating the average test results of 5 specimens, the tensile strength of each variation in the angle of the hybrid laminate slats can be determined.

Table 1. Tensile test results

\begin{tabular}{|c|c|c|c|c|c|c|c|}
\hline \multirow[b]{2}{*}{$\begin{array}{l}\text { Hybrid } \\
\text { Laminate } \\
\text { variation }\end{array}$} & \multirow[b]{2}{*}{$\begin{array}{c}\text { Spec. } \\
\text { No. }\end{array}$} & \multicolumn{6}{|c|}{ Test result } \\
\hline & & $\begin{array}{c}\text { Tensile } \\
\text { Strength } \\
\text { (Mpa) }\end{array}$ & $\begin{array}{c}\text { MOE } \\
\text { (Gpa) }\end{array}$ & $\begin{array}{c}\text { Strain } \\
(\%)\end{array}$ & $\begin{array}{c}\text { Tensile } \\
\text { Strength } \\
\text { Average } \\
\text { (Mpa) }\end{array}$ & $\begin{array}{l}\text { MOE } \\
\text { Average } \\
\text { (Gpa) }\end{array}$ & $\begin{array}{c}\text { Strain } \\
\text { Average } \\
(\%)\end{array}$ \\
\hline \multirow{5}{*}{$\begin{array}{l}\text { Parallel } \\
\text { slat layers } \\
\left(0^{\circ}\right)\end{array}$} & 1 & 103.75 & 11.93 & 40,31 & \multirow{5}{*}{114.64} & \multirow{5}{*}{11.90} & \multirow{5}{*}{38.44} \\
\hline & 2 & 124.05 & 13.62 & 38.28 & & & \\
\hline & 3 & 130.98 & 12.31 & 38.13 & & & \\
\hline & 4 & 122.05 & 11.49 & 37.97 & & & \\
\hline & 5 & 102.35 & 10.18 & 39.38 & & & \\
\hline \multirow{5}{*}{$\begin{array}{l}\text { Transverse } \\
\text { slat layers } \\
\left(45^{\circ}\right)\end{array}$} & 1 & 55.43 & 9.92 & 35.78 & \multirow{5}{*}{53.81} & \multirow{5}{*}{10.41} & \multirow{5}{*}{33.94} \\
\hline & 2 & 39.60 & 11.93 & 21.25 & & & \\
\hline & 3 & 52.55 & 11.15 & 30.16 & & & \\
\hline & 4 & 66.83 & 8.95 & 47.81 & & & \\
\hline & 5 & 54.65 & 10.08 & 34.69 & & & \\
\hline \multirow{5}{*}{$\begin{array}{l}\text { Transverse } \\
\text { slat layers } \\
\left(90^{\circ}\right)\end{array}$} & 1 & 79.04 & 8.87 & 37.03 & \multirow{5}{*}{80.07} & \multirow{5}{*}{10.45} & \multirow{5}{*}{37.15} \\
\hline & 2 & 80.77 & 9.11 & 38.72 & & & \\
\hline & 3 & 83.49 & 15.13 & 35.31 & & & \\
\hline & 4 & 79.60 & 9.21 & 36.7 & & & \\
\hline & 5 & 77.47 & 9.92 & 38 & & & \\
\hline \multirow{5}{*}{$\begin{array}{l}\text { Transverse } \\
\text { slat layers } \\
\left(135^{\circ}\right)\end{array}$} & 1 & 90.44 & 11.03 & 38.5 & \multirow{5}{*}{72.95} & \multirow{5}{*}{9.83} & \multirow{5}{*}{37.54} \\
\hline & 2 & 82.15 & 8.72 & 37.42 & & & \\
\hline & 3 & 56.53 & 8.71 & 35.56 & & & \\
\hline & 4 & 72.97 & 9.90 & 39.19 & & & \\
\hline & 5 & 62.65 & 10.83 & 37.03 & & & \\
\hline
\end{tabular}

The difference in the average tensile strength value can be explained based on the variation in the angle of the laminate slats and can be seen in Figure 4. Figure 4 shows that the highest tensile strength value is lamination with parallel slats, which is $114.64 \mathrm{MPa}$ with MOE $11.90 \mathrm{GPa}$ and strain $38.44 \%$. If we pay attention to the calculation results of the 4 slats angle variations, the MOE and strain values only have small differences. So, all variations meet the BKI's tensile strength requirements of $42.169 \mathrm{MPa}$ and they can be used as ship materials. Nevertheless, the parallel slat layers are the best variation to be used as fishing boat construction materials because it has the highest tensile strength and modulus of elasticity (MoE). 


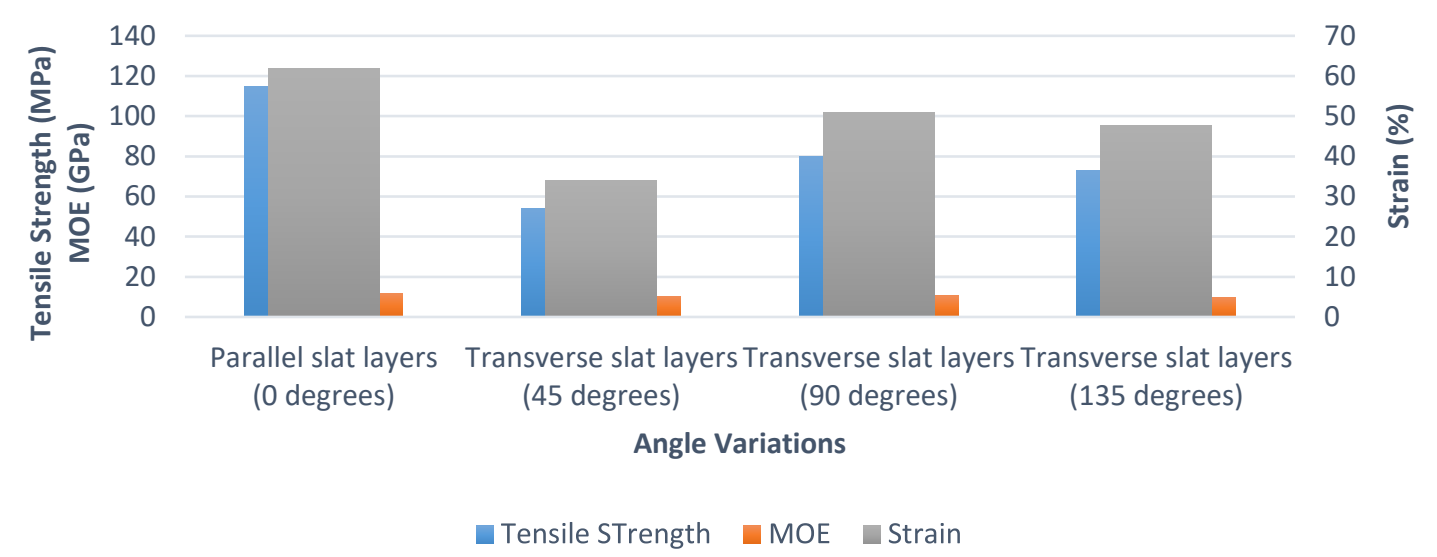

Figure 4. Graph of tensile strength of hybrid laminate Pterocarpus indicus with Bambusa arundinacea slats

\subsection{Flexure Test Results}

The tensile test results for all variations can be seen in Table 2. The results of the Modulus of Rupture (MoR) and Modulus of Elasticity (MoE) are all calculated based on ASTM D3024. Determining the value of MoR and MoE from each variation is done by averaging the test results of the five specimens. The four variations of fibre direction turned out to have a fairly large range of MoR and MoE values between 33.06-128.73 MPa for MoR and 7.12-12.74 GPa for MoE.

Table 2. Flexure Test Results

\begin{tabular}{lccccccc}
\hline \multirow{2}{*}{$\begin{array}{l}\text { Hybrid } \\
\text { Laminate } \\
\text { variation }\end{array}$} & $\begin{array}{c}\text { Spec. } \\
\text { No }\end{array}$ & $\begin{array}{c}\text { Deflection } \\
(\mathbf{m m})\end{array}$ & $\begin{array}{c}\text { MOR } \\
(\mathbf{M p a})\end{array}$ & $\begin{array}{c}\text { MOE } \\
(\mathrm{Gpa})\end{array}$ & $\begin{array}{c}\text { Deflection } \\
\text { average } \\
(\mathbf{m m})\end{array}$ & $\begin{array}{c}\text { MOR } \\
\text { average } \\
(\mathbf{M p a})\end{array}$ & $\begin{array}{l}\text { MOE } \\
\text { average } \\
(\mathrm{Gpa})\end{array}$ \\
\hline & 1 & 21.6 & 106.46 & 11.57 & & & \\
Parallel slat & 2 & 20.5 & 104.04 & 12.74 & & & \\
layers $\left(0^{\circ}\right)$ & 3 & 21.5 & 119.99 & 10.29 & 21.22 & 111.60 & 11.702 \\
& 4 & 22.8 & 98.79 & 11.57 & & & \\
& 5 & 19.7 & 128.73 & 12.34 & & & \\
& 1 & 18.60 & 92.56 & 10.27 & & & \\
Transverse slat & 2 & 13.40 & 73.09 & 11.37 & & & \\
layers $\left(45^{\circ}\right)$ & 3 & 15.40 & 28.51 & 10.78 & & & \\
& 4 & 12.40 & 61.18 & 9.97 & 15.06 & 68.40 & \\
& 5 & 15.50 & 86.66 & 11.48 & & & \\
\hline & 1 & 10.40 & 70.09 & 9.92 & & & \\
Transverse slat & 2 & 9.40 & 77.99 & 11.96 & & & \\
layers $\left(90^{\circ}\right)$ & 3 & 9.80 & 61.94 & 9.32 & & & \\
& 4 & 8.70 & 59.48 & 10.25 & 9.50 & 70.41 & \\
& 5 & 9.20 & 82.55 & 9.46 & & & \\
\hline & 1 & 9.00 & 38.20 & 7.63 & & & \\
Transverse slat & 2 & 8.40 & 33.06 & 7.12 & & & \\
layers $\left(135^{\circ}\right)$ & 3 & 10.10 & 35.09 & 7.42 & & & \\
& 4 & 9.60 & 45.19 & 8.68 & 9.18 & 39.63 & \\
& 5 & 8.80 & 46.60 & 9.80 & & & \\
\hline
\end{tabular}




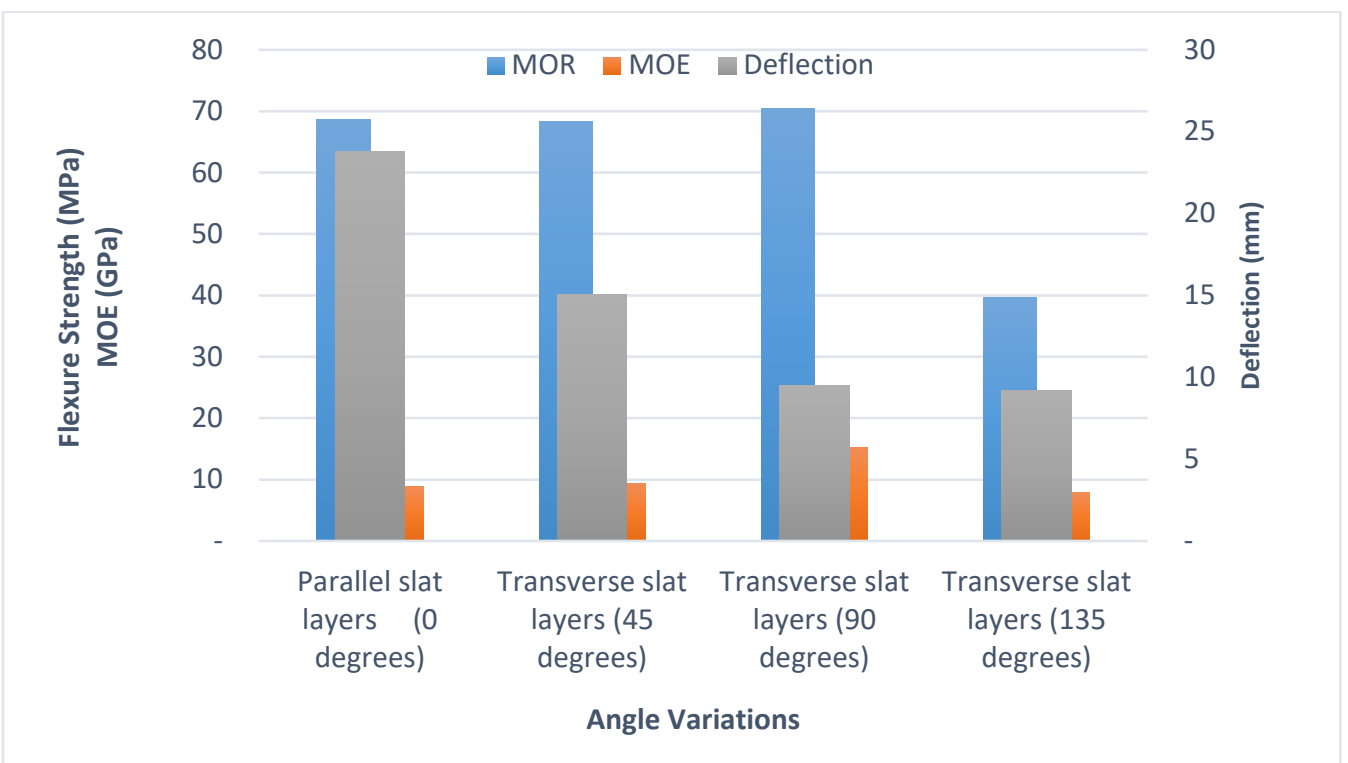

Figure 5. Graph of average flexure strength

However, by carefully observing the test results and the calculation of the flexure strength of the 25 specimens, it can be said that the MOE value between variations of the slat angle has no significant difference. A rather striking difference is in the deflection value, namely the variation in the angle of the parallel slats of $21.22 \mathrm{~mm}$, while for the variation of the slats angle of $90^{\circ}$ and combined $45^{\circ}$ and $135^{\circ}$, it is only about $9.5 \mathrm{~mm}$ and $9.1 \mathrm{~mm}$, respectively. In accordance with Table 2 and Figure 5, it can be said that the variation of the angle of the laminated slats $0^{\circ}$ (parallel) meets the allowable flexure stress $\geq$ $72.098 \mathrm{Mpa}[9]$. Thus, the chosen variation of hybrid slats laminated material between Petrocarpus indicus and Bambusa arundinacea is parallel slat variation $\left(0^{\circ}\right)$.

\subsection{Scantling Calculation}

The values of tensile strength, flexure, and modulus of elasticity are variables in determining the size of the fishing boat construction components. To prove that this hybrid slats lamination material can reduce the size of fishing boat construction members, this hybrid slat lamination material will be applied to the 20 GT fishing boat. Fishing boats as the case in this study usually operate in Brondong sub-district, Lamongan, East Java. The main size of the 20 GT fishing boat, which is the main variable for calculating the load and construction size, is presented in Table 3.

\begin{tabular}{lll} 
Table 3. Main dimensions of 20 GT fishing boat \\
\hline Dimension & \multicolumn{2}{l}{ Value } \\
\hline Length over all (LOA) & 12 & $\mathrm{~m}$ \\
Length of water line (LWL) & 11.4 & $\mathrm{~m}$ \\
Breadth moulded ( Bmld) & 4 & $\mathrm{~m}$ \\
Height (H) & 3.75 & $\mathrm{~m}$ \\
Draught (T) & 1.58 & $\mathrm{~m}$ \\
Coeficien Block (Cb) & 0.72 & \\
Velocity (Vs) & 8 & knot \\
\hline
\end{tabular}

Based on the provisions and formulas required by the Indonesian Classification Bureau vol: vii, 2013, the size of the ship construction components is calculated. The variables used are tensile strength, flexure strength, and MoE. The calculation of the size of the fishing boat construction was carried out on the hybrid lamination material of Petrocarpus indicus wood slats with Bambusa arundinacea compared to solid teak wood material. The results of the 20 GT fishing boat scantling calculation can be seen in Table 4.

Table 4. The results of the 20 GT fishing boat scantling calculation

\begin{tabular}{lcccc}
\hline \multirow{2}{*}{ Construction members } & \multicolumn{2}{c}{ Hybrid Slats Laminate } & \multicolumn{2}{c}{ Teak Solid Wood } \\
\cline { 2 - 5 } & Face $(\mathbf{m m})$ & Web $(\mathbf{m m})$ & Face $(\mathbf{m m})$ & Web $(\mathbf{m m})$ \\
\hline Keel & 200 & 285 & 220 & 340 \\
Stern/stem Frame & 180 & 220 & 190 & 280 \\
Ordinary frame & 110 & 170 & 125 & 194 \\
Deck Stranger & 50 & 150 & 61 & 295 \\
Side Stranger & 50 & 135 & 96 & 96 \\
Bilge stranger & 45 & 140 & 57 & 245 \\
Deck beam & 110 & 170 & 125 & 194 \\
\hline
\end{tabular}


Sheel

Main deck

Superstructure wall

Super structure deck

Floor

\begin{tabular}{cccc}
\hline Thickness (mm) & $\begin{array}{c}\text { Height } \\
(\mathbf{m m})\end{array}$ & $\begin{array}{c}\text { Thickness } \\
(\mathbf{m m})\end{array}$ & $\begin{array}{c}\text { Height } \\
(\mathbf{m m})\end{array}$ \\
\hline 36 & - & 42 & - \\
35 & - & 51 & - \\
36 & 2500 & 51 & 2500 \\
30 & - & 45 & - \\
69 & 285 & 85 & 285 \\
\hline
\end{tabular}

Table 4 explains that almost all the dimensions of the fishing boat construction components made of hybrid slat laminate are smaller than solid Teak wood. An explanation of the size of this construction will represent the overall volume of material requirements for fishing boat construction. To find out how much the reduction in material for the construction of a 20 GT fishing boat made from hybrid laminates, the volume of all parts of the construction should be calculated.

By calculating the volume of fishing boat building material, both for solid teak wood and hybrid slat laminates, the total amount of material for construction is obtained. The result of total material requirements for this construction will be tabulated and compared with one another. Table 5 shows that the volume of material requirements for hybrid slats of Petrocarpus indicus and Bambusa arundinacea is $4.92 \mathrm{~m}^{3}$ smaller than that of solid teak. Thus, it can be said that if this hybrid laminate material is likely to be able to replace solid teak wood as a fishing boat material.

Table 5. Volume of construction materials for 20 GT fishing vessels

\begin{tabular}{llll}
\hline $\begin{array}{l}\text { Construction } \\
\text { members }\end{array}$ & $\begin{array}{l}\text { Volume }\left(\mathrm{m}^{3}\right) \\
\text { Solid Teak } \\
\text { wood }\end{array}$ & $\begin{array}{l}\text { Hybrid slats } \\
\text { laminate }\end{array}$ & $\begin{array}{l}\text { volume difference } \\
\left(\mathrm{m}^{3}\right)\end{array}$ \\
\hline Keel & 0.75 & 0.57 & 0.18 \\
Stem/Stern frame & 0.32 & 0.24 & 0.08 \\
Ordinary frame & 4.77 & 3.68 & 1.09 \\
Deck stranger & 0.51 & 0.21 & 0.30 \\
Side stranger & 0.26 & 0.19 & 0.07 \\
Bilge stranger & 0.39 & 0.18 & 0.22 \\
Deck beam & 3.36 & 2.86 & 0.50 \\
sheel & 3,35 & 2.39 & 0.96 \\
Main deck & 1.79 & 0.91 & 0.88 \\
Super structure wall & 0.83 & 0.59 & 0.24 \\
Super structure deck & 0.79 & 0.37 & 0.42 \\
Floor & 4.87 & 3.78 & 1.09 \\
\hline \multicolumn{1}{c}{ TOTAL } & $\mathbf{1 7 . 1 1}$ & $\mathbf{1 2 . 1 9}$ & $\mathbf{4 . 9 2}$ \\
\hline
\end{tabular}

\subsection{Production Cost Calculation of 20 GT Fishing Boat}

After calculating the volume of fishing boat construction material requirements, the construction costs will then be compared with the materials commonly used. Many studies have analyzed the cost of constructing a fishing boat. The price of fishing boats is increasingly expensive, this is due to high prices and increasingly scarce materials.

The components of the cost of building a fishing boat made from laminated wooden slats include: Materials and adhesives, labor, consumables, overhead costs. To make a fishing boat with different materials, the cost component will be different [4]. In this research, a fishing boat made of hybrid slat laminates between Pterocarpus indicus and Bambusa arundinacea, was built simply by carrying out a simple printing process according to the Lines Plan. Meanwhile, for fishing boats made of solid teak wood, it is necessary to form solid wood rods according to the shape of each component of the fishing boat hull construction. Factor on the number of processes and equipment also determines the total cost needed to build a fishing boat. The difference in the amount of fishing boat construction costs between the 2 types of wood-based materials in this study can be seen in Table 6.

Table 6. Construction cost of 20 GT fishing boat

\begin{tabular}{lll}
\hline \multicolumn{1}{c}{ Item } & \multicolumn{3}{l}{ Total sub cost (IDR) } \\
\hline Main material and adhesive cost & $306,423,300$ & $550,126,888$ \\
Labour cost & $86,233,538$ & $127,216,843$ \\
Consumable cost & $65,454,751$ & $96,562,741$ \\
Overhead cost & $4,860,000$ & $6,240,000$ \\
\hline Total Construction cost & $\mathbf{4 6 2 , 9 7 1 , 5 8 9}$ & $\mathbf{7 8 0 , 1 4 6 , 4 7 2}$ \\
\hline
\end{tabular}




\begin{tabular}{ll}
\hline Difference in construction costs (IDR) & $\mathbf{3 1 7 , 1 7 4 , 8 8 3}$ \\
\hline $\begin{array}{l}\text { Percentage of difference in construction } \\
\text { costs }(\%)\end{array}$ & $\mathbf{4 0 . 6 6}$ \\
\hline
\end{tabular}

Table 6 can explain that the total cost of fishing boat construction using laminated hybrid slats of Pterocarpus indicus with Bambusa arundinacea is IDR $317,174,883$ or $40.66 \%$ lower than solid teak wood. Thus, economically, it can be said that the utilization of this hybrid slat laminate can be further developed commercially in the future.

\subsection{Discussion}

The previous description explained that the availability of solid teak is increasingly rare and the price tends to ascend. Thus, substitution materials such as a hybrid laminate of Pterocarpus indicus slats with Bambusa arundinacea are very necessary to maintain the sustainability of the fishing boat dock. Moreover, recently there are many shipyards and the number of fishing boats has decreased due to the scarcity of construction materials $[13,14]$.

According to the results of the mechanical properties test, it is possible to use hybrid lamination of Pterocarpus indicus slats with tr. This is evidenced by the tensile strength and flexure strength that meet the requirements of the Indonesian Classification Bureau vol: vii 2013. Even the mechanical properties of this hybrid slat lamination can be said to be quite adequate from the point of view of technical factors and very adaptable to use as ship material [15].

With greater mechanical properties than solid teak wood, hybrid lamination of Pterocarpus indicus slats with Bambusa arundinacea can reduce the scantling size of fishing boat construction by $28.75 \%$. Thus, it will be able to increase the efficiency in the use of fishing boat building materials.

In accordance with the fishing boat building method, the use of solid teak wood requires several more processes when compared to the hybrid material of Pterocarpus indicus slat lamination with Bambusa arundinacea. The striking difference is that there is a process of forming wooden blocks according to the arch of the body of the ship. Meanwhile, with hybrid lamination, it is enough to laminate directly according to the lines plan [16].

In accordance with the results of the construction cost analysis, the use of a hybrid laminate of Pterocarpus indicus slats with Bambusa arundinacea can be minimized as realistic as possible. When compared with solid teak wood material, this hybrid slat lamination can reduce the cost of building a 20 GT fishing boat by $40.66 \%$. So economically, hybrid lamination of Pterocarpus indicus slats with Bambusa arundinacea is highly recommended, especially for traditional shipyards which have very simple equipment [17].

Based on the recommendations of international communities regarding forest sustainability, the use of hybrid Pterocarpus indicus lamination with Bambusa arundinacea can be implemented because it has several advantages, including: sustainable, renewable and environmentally friendly. So that the use of this hybrid laminate for fishing boat construction is in line with the green industry in the maritime field [18].

\section{Conclusion}

Several main points related to the comparison of the hybrid slats laminate material Pterocarpus indicus with Arundinacea bambusa can be concluded as follows:

1) The variation of fibre direction that has the highest mechanical strength is the parallel variation. The variation has a tensile strength of 114.64 MPa and a flexure strength of 106.46 MPa. According to ASTM regulations (D3500 for tensile test and D3024 for flexure test), this variation has a MoE for tensile strength of $11.90 \mathrm{GPa}$ and MoE for flexure strength of 11.702 GPa.

2) The lamination of Pterocarpus indicus hybrid slats with Bambusa arundinacea can be used as a construction material for fishing boats. The test results show that only two variations of fibre direction can meet the BKI standard, namely parallel variations (42.169 MPa for tensile strength and $72.098 \mathrm{MPa}$ for flexural tests). This is because although all variations meet the tensile strength requirements, only parallel variations meet the flexural test requirements.

3) The usage of the hybrid slats laminates material Pterocarpus indicus with Bambusa arundinacea for fishing boat construction material has a high economic value. After being simulated using a $20 \mathrm{GT}$ fishing boat, this material can reduce the construction volume of material requirements by $28.7 \%$ when compared to the use of solid teak wood. This decrease in material requirements also resulted in a decrease in costs of IDR $317,174,883$ or $40.66 \%$.

\section{Acknowledgements}

The authors would like to thank those who have helped, especially the Laboratory of Technology and Production Management, Department of Marine Engineering, Faculty of Marine Technology, Sepuluh Nopember Institute of Technology.

\section{References}

[1] K. G. Austin, A. Schwantes, Y. Gu, and P. S. Kasibhatla, "What causes deforestation in Indonesia?," Environ. Res. Lett., 2019, doi: 10.1088/1748-9326/aaf6db.

[2] A. A. Nawir and L. Rumboko, Sejarah dan Kondisi Deforestasi dan Degradasi Lahan. 2008.

[3] H. Supomo, "The use of bamboo slats laminate as a renewable construction material for East Java traditional fishing boat," Journal of Ocean Technology., vol. 14, 2019. 
[4] H. Supomo, E. B. Djatmiko, S. Nugroho, R. E. Kurt, and T. Tezdolan, "Study on the utilisation of laminted bamboo (Bambusa arundinacea) slats as an alternative Composite Material for building smail fishing boat framing structures," Transactions of the Royal Institution of Naval Architects Part B International Journal Small Craft Technology, 2018, doi: 10.39401rina/ijsct.2018.b2.221.

[5] M. Penellum, B. Sharma, D. U. Shah, R. M. Foster, and M. H. Ramage, "Relationship of structure and stiffness in laminated bamboo composites," Construction and Building Materials, 2018, doi: 10.1016/j.conbuildmat.2017.12.166.

[6] B. Sharma, H. Bauer, G. Schickhofer, and M. H. Ramage, "Mechanical characterisation of structural laminated bamboo," ICE Proceedings Structures and Buildings., 2017, doi: 10.1680/jstbu.16.00061.

[7] T. A. Amatosa and M. E. Loretero, "Bamboo Waste-based Bio-composite Substance: An application for Low-cost Construction Materials," SPECTA Journal of Technology, 2020, doi: 10.35718/specta.v4i1.162.

[8] A. R. Taufani and A. S. B. Nugroho, "Proposed bamboo school buildings for elementary schools in Indonesia," Procedia Engineering, vol. 95, 2014, doi: 10.1016/j.proeng.2014.12.159.

[9] Indonesian Classification Bureau, Rules for small vessel up to $24 \mathrm{~m} 2013$ edition Indonesian Classification Bureau, vol. VII. Jakarta: Indonesian Classification Bureau, 2013.

[10] H. Supomo, D. Manfaat, and A. Zubaydi, "Flexural strength analysis of laminated bamboo slats (Bambusa arundinacea) for constructing a small fishing boat shells," Transactions of the Royal Institution of Naval Architects Part B International Journal Small Craft Technology., vol. 157, no. Part B1, 2015, doi: 10.3940/nna.ijsct.2015.bl.167.

[11] ASTM, "Standard Test Methods for Structural Panels in Shear Through-the-Thickness," Astm D3500, vol. 04, no. December 1990, pp. 1-32, 2013.

[12] ASTM, "Standard Test Methods for Structural Panels in Shear Through-the-Thickness," Astm D3043, vol. 04, no. December 1990, pp. 1-36, 2013.

[13] T. Reynolds, B. Sharma, K. Harries, and M. Ramage, "Dowelled structural connections in laminated bamboo and timber," Composite Part B: Engineering, vol. 90, 2016, doi: 10.1016/j.compositesb.2015.11.045.

[14] S. Henders, U. M. Persson, and T. Kastner, "Trading forests: Land-use change and carbon emissions embodied in production and exports of forest-risk commodities," Environmental Research Letters., 2015, doi: 10.1088/17489326/10/12/125012.

[15] E. E. Gdoutos, "Composite Materials," in Solid Mechanics and its Applications, 2020.

[16] J. Song, C. Chen, S. Zhu, M. Zhu, J. Dai, U. Ray, Y. Kuang, Y. Li, N. Quispe, Y. Yao, A. Gong, U. H. Leiste, H. A. Bruck, J. Y. Zhu, A. Vellore, H. Li, M. L. Minus, Z. Jia, A. Martini, T. Li, L. Hu., "Processing bulk natural wood into a high-performance structural material," Nature, vol, 554, 2018, doi: 10.1038/nature25476.

[17] S. K. Mazumdar, Composites manufacturing: Materials, product, and process engineering. 2001.

[18] R. A. Sá Ribeiro, M. G. Sá Ribeiro, K. Sankar, and W. M. Kriven, "Geopolymer-bamboo composite - A novel sustainable construction material," Construction and Building Materials., vol.123, 2016, doi: 10.1016/j.conbuildmat.2016.07.037. 